\title{
Perbandingan Keterampilan Motorik Kasar Anak Kelompok B pada Kegiatan Senam Berirama dan yang Tidak Berirama
}

\author{
Ani Marlia \\ Titin Faridatun Nisa' \\ Yulias Wulani Fajar \\ Program Studi Pendidikan Guru Pendidikan Anak Usia Dini Fakultas Ilmu Pendidikan \\ Universitas Trunojoyo Madura \\ Email: animarlia42@gmail.com, titinfaridatunnisa@trunojoyo.ac.id, wholand@yahoo.com
}

Received August 2018, Accepted September 2018, Published October 2018

\begin{abstract}
The aim of this study is to compare applying music through gross motor skill towards kid's Class $B$ Kindergarten on gymnastic. This study using comparative quantitative approach with 30 kids; 15 boys and 15 girls as the research subject. It takes from the population of Ulil Albab Kindergarten students using purposive sampling considers criteria towards their development. Observation and documentation technique are applied as data interpretation. Therefore, the instrument of study utilizes observation sheet from the kid's gymnastics at school. The data analysis uses statistic non-parametric. Wilcoxon test is used in this study as the hypothesis result. Ensue from the computation SPSS 19.0 is as two directions significant 0, 00. According to this significant $<0,05$ thus Ho is confirmed. This shows there is no difference of gross motor towards Class B kids in using music on gymnastics.
\end{abstract}

Keywords: Kindergarten, Gross Motor, Gymnastics.

\begin{abstract}
Abstrak: Penelitian ini bertujuan untuk mengetahui perbandingan keterampilan motorik kasar anak kelompok B pada kegiatan senam yang menggunakan dan tidak menggunakan irama. Penelitian ini menggunakan pendekatan kuantitatif metode komparatif. Subjek penelitian ini 30 anak, dengan jumlah murid laki-laki 15 dan murid perempuan 15. Populasi dari penelitian ini seluruh murid RA Ulil Albab Kamal. Dengan teknik pengumpulan data melalui observasi dan dokumentasi. Teknik analisis data yang digunakan adalah statistik nonparametris. Hasil hipotesis dalam penelitian ini menggunakan uji Wilcoxon. Dari hasil perhitungan menggunakan SPSS 19.0 diperoleh nilai signifikansi uji dua arah sebesar 0,00, karena signifikansi $<0,05$ maka Ho Diterima. Hal ini menunjukkan bahwa tidak ada perbedaan keterampilan motorik kasar anak kelompok B yang menggunakan dan tidak menggunakan irama.
\end{abstract}

Kata Kunci: Anak Usia Dini, Motorik Kasar, Senam Irama

\section{PENDAHULUAN}

Kualitas sebuah negara dapat dilihat dari sistem pendidikan dan sumber daya manusianya. Pendidikan berlangsung melalui berbagai bentuk kegiatan, tindakan, dan kejadian, baik pada awalnya yang disengaja untuk pendidikan. (Mujtahidin \& Rasyid, 2014) Pendidikan sendiri berarti konsep mendidik yang diwujudkan dalam bentuk perbuatan atau cara mendidik yang dilakukan oleh manusia pada umumnya. Pendidikan merupakan suatu kegiatan yang menjadikan manusia ke arah lebih baik, dengan mencetak generasi terpelajar, terdidik, dan bermoral. Orang tua memiliki peran penting terhadap proses tumbuh kembang anak. Oleh karena itu, orang tua harus memberikan lingkungan tempat tinggal yang nyaman, sehingga anak-anak dapat mengeksplor potensi di lingkungan tempat tinggalnya.
Orang tua memiliki peran penting terhadap proses tumbuh kembang anak. Maka orang tua harus memberikan lingkungan tempat tinggal yang nyaman, sehingga anak-anak dapat mengeksplor potensi di lingkungan tempat tinggalnya. Anak usia dini memiliki potensi dalam mengembangkan aktivitas gerak tubuhnya, yang melibatkan otot tangan dan kaki, dimana perkembangan gerak sangat penting bagi bayi dan balita karena menunjang perkembangan intelektual dan keterampilan mereka dalam beraktivitas. Kemampuan anak usia 5-6 tahun Taman Kanak-kanak sangat berkembang pesat, tidak dipungkiri perkembangan fisik motoriknya pun ikut berkembang.

Proses tumbuh kembang motorik anak juga sangat dipengaruhi oleh kegiatan sehariharinya. Anakanak pada rentang usia 5-7 tahun sangat membutuhkan gerak. Maka pemberian 
Jurnal PG-PAUD Trunojoyo : Jurnal Pendidikan dan Pembelajaran Anak Usia Dini,

aktivitas jasmani untuk anak yang memadai dan sesuai dengan kebutuhan mereka sangatlah penting. (Muhyi, 2016) Salah satu kegiatan untuk melatih gerakan pada anak usia dini yaitu dengan melakukan senam, melalui olahraga senam anak dapat mengembangkan gerak dan keterampilan motorik kasarnya. Senam dapat melatih kekuatan tubuh seperti kelenturan, keseimbangan, kelincahan. Sehingga melalui aktivitas senam yang di dalamnya melibatkan gerakan kelenturan, keseimbangan dan kelincahan, keterampilan motorik kasar anak dapat berkembang.

Anak usia dini memiliki rentang usia yang sangat berharga dibanding usia-usia selanjutnya karena perkembangan kecerdasannya sangat luar biasa. Secara yuridis, istilah anak usia dini Indonesia ditujukan kepada anak sejak lahir sampai dengan usia enam tahun. Undang-Undang Sistem Pendidikan Nasional Nomor. 20 Tahun 2003 pasal 28 ayat 1, disebutkan bahwa yang termasuk anak usia dini adalah anak yang masuk dalam rentang usia 0-6 tahun. (Depdiknas, 2006)Anak usia dini merupakan individu yang berbeda, unik, dan memiliki karakteristik tersendiri sesuai dengan tahapan usianya. Anak usia dini dibagi menjadi tiga kelompok, yaitu kelompok bayi hingga 2 tahun, kelompok 3 hingga 5 tahun, dan kelompok 6 hingga 8 tahun. Berdasarkan keunikan dan perkembangannya, anak usia dini terbagi menjadi tiga tahapan, yaitu masa bayi lahir sampai 12 bulan, masa batita (toddler) usia 1-3 tahun, masa prasekolah 3-6 tahun, dan masa kelas awal 6-8 tahun. (Fadilah, 2012)

Perkembangan merupakan sebuah proses perubahan yang terjadi pada diri manusia. perkembangan ialah perubahan progresif yang menunjukkan organisme bertingkah laku dan berinteraksi dengan lingkungan. (Fadilah, 2012) Perkembangan anak dapat dilihat dari kegiatan sehari-hari dengan mengamati dan memahami apa yang dilakukan anak.

Seorang anak berkembang setelah anak tersebut mengalami kontak dan pengalaman dengan orang-orang di sekitarnya. Gambaran pola perkembangan yang tepat merupakan dasar untuk memahami anak-anak. (Hurlock, 2013) Anak akan mengamati lingkungan tempat tinggalnya dan pada saat itu anak mulai berkembang sesuai dengan pengalaman yang didapat. Dari pengalaman tersebut anak bisa mengambil pelajaran untuk

diterapkan dalam kehidupan seharihari, dengan demikian seorang anak berkembang lewat apa yang mereka lihat dan kemudian dipraktekkan.

Pada masa anak-anak, perkembangan motorik sangat pesat sesuai usianya. Perkembangan motorik adalah proses sejalan dengan bertambahnya usia secara bertahap dan berkesinambungan. (Susanto, 2014) Tahap perkembangan motorik anak berpengaruh dengan kecerdasan anak. Perkembangan motorik sangat esensial karena berkontribusi besar bagi perkembangan intelektual dan keterampilan anak. (Morrison, 2016)

Perkembangan koordinasi otot-otot besar motorik anak mengandalkan koordinasi gerakan tubuh. perkembangan motorik adalah proses seorang anak belajar untuk terampil menggerakkan anggota tubuh. (Mursid, 2015) Perkembangan koordinasi gerakan tubuh berperan dalam gerak motorik kasar anak-anak ketika melakukan aktivitas seharihari. motorik kasar adalah melatih gerakan jasmani berupa koordinasi gerakan tubuh pada anak, seperti merangkak, berlari, berjinjit, melompat bergantung, melempar, dan menangkap, serta menjaga keseimbangan. (Mursid, 2015)

Motorik kasar merupakan kegiatan yang melibatkan semua fisik tubuh. Motorik kasar adalah gerakan yang dilakukan melibatkan sebagaian besar anggota tubuh dan memerlukan tenaga karena melibatkan otot-otot besar. (Susanto, 2014)Gerak motorik kasar, menggunakan otot-otot besar dalam melakukan gerakan dalam beraktivitas. Proses tumbuh kembang anak berhubungan dengan tumbuh kembang gerak anak. Ada macam-macam gerakan dalam melatih gerakan motorik kasar anak. Yaitu berjalan, berlari, meloncat, menyepak, melempar menangkap dan hal yang harus diperhatikan adalah pengawasan anak saat proses belajar merangsang gerakan motorik kasar. Anak dapat bergerak aktif mengeksplor lingkungan dan mengasah gerakan motorik kasar.

Aktivitas motorik kasar banyak
melibatkan kerja otot-otot besar
melakukan gerak dasar. Kemampuan
dasar dibagi menjadi tiga, yaitu:

a. Gerak Nonlokomotor 
Gerakan yang tidak berpindah tempat, seperti menekuk, membungkuk, menarik, mendorong, meregang, memutar, mengangkat, mengayun, merentang, dan merendahkan tubuh.

b. Gerak Lokomotor

Gerakan yang berpindah tempat atau memindahkan tubuh dari tempat satu ke tempat lain. Seperti berlari, berjalan, meloncat, berguling, dan meluncur.

c. Gerak Manipulatif

Gerakan yang menggunakan objek atau alat bantu sebagai medianya. Seperti menendang bola, memukul, dan menangkap. (Sumantri, 2005)

Melalui senam motorik kasar dapat distimulus dengan gerakan-gerakannya. Senam merupakan salah satu kegiatan yang terstruktur gerakan dan pelaksanaannya. Senam dalam terjemahan kata dari Bahasa Inggris Gymnastic yang berasal dari Bahasa Yunani Gymnos yang artinya telanjang. Senam dapat diartikan sebagai latihan jasmani yang dilakukan dengan sengaja, disusun secara sistematis, dan dilakukan dengan sabar dengan tujuan tertentu (Syarifuddin, 2014). Senam merupakan kegiatan latihan fisik yang tersusun secara terencana dan sistematis yang melibatkan gerak anggota tubuh.

Senam terdiri dari dua jenis, yakni senam irama dan senam tak berirama. Senam irama adalah gerakan senam yang dilakukan dengan irama atau musik atau aktivitas gerak yang dilakukan secara berirama, irama yang dimaksud dapat berupa musik, hitungan atau ketukan (Syarifuddin, 2014). Senam irama maupun gerak ritmik merupakan kegiatan yang mengekspresikan gerak tubuh.

Senam irama merupakan kegiatan fisik yang dapat merangsang gerakan motorik kasar anak. senam irama merupakan aktivitas jasmani yang efektif untuk mengoptimalkan pertumbuhan dan perkembangan. (Muhajir, 2007) Melalui senam irama keterampilan motorik kasar anak dapat bekerja dengan baik karena terstimulus oleh gerakan-gerakan yang melibatkan seluruh anggota badan dan membuat tulang kuat. Kegiatan berolahraga akan membuat tulang dan otot anak bertambah kuat dan banyaknya akitivitas bergerak juga akan mengontrol berat badan anak yang gemuk. (Sujino, 2014)
Beberapa aspek perkembangan motorik kasar ada yang harus dikembangankan dalam diri anak usia dini, seperti melakukan koordinasi gerakan mata, kaki, tangan, dan kepala. Keempat aspek tersebut diharapkan dapat menumbuh kembangkan perkembangan motorik kasar anak. Berdasarkan observasi pertama di RA Ulil Albab Kamal, diperoleh gambaran bahwa anak-anak kelas B keterampilan motorik kasarnya belum terlihat perbedannya ketika melaksanakan kegiatan senam. Hal ini terlihat ketika kegiatan senam berlangsung, baik senam yang menggunakan irama dan tidak menggunakan irama belum ada perbedaan secara signifikan dalam perkembangan keterampilan motorik kasar anak.

Berdasarkan uraian di atas, selain stimulus dari alat-alat bermain dalam mengembangkan keterampilan motorik kasar anak. Aktivitas jasmani berupa senam juga dapat diterapkan. Dalam kegiatan senam yang pernah dilakukan, guru belum pernah membandingkan dua senam tersebut, untuk melihat perbedaan keterampilan motorik kasar anak. Sehingga dalam penelitian ini, peneliti ingin mengkaji lebih dalam tentang "Perbandingan Keterampilan Motorik Kasar Anak Kelompok B Pada Kegiatan Senam Yang Menggunakan Dan Tidak Menggunakan Irama di RA Ulil Albab Kecamatan Kamal Kabupaten Bangkalan".

\section{METODE PENELITIAN}

Penelitian ini dilakukan di RA Ulil Albab yang beralamat Jl. Sumbersari No. 22, Banyuajuh Kecamatan Kamal Kabupaten Bangkalan. Penelitian menggunakan dua populasi, yaitu populasi anak yang menggunakan senam irama (Variabel $\mathrm{X}_{1}$ ) dan populasi siswa yang tidak menggunakan senam irama (Variabel $\mathrm{X}_{2}$ ) dengan melakukan pendekatan Kuantitatif komparatif . Teknik sampling yang digunakan dalam penelitian ini adalah sampling purposive, sampel yang diambil berjumlah 30 siswa. Penelitian ini mengguanakan sampling purposive dengan mengambil subyek dengan tujuan tertentu, yaitu bertujuan untuk mengetahui perbandingan keterempilan motorik kasar anak kelompok B yang menggunakan dan tidak menggunakan irama. 
Jurnal PG-PAUD Trunojoyo : Jurnal Pendidikan dan Pembelajaran Anak Usia Dini,

Teknik pengumpulan data pada penelitian ini yaitu observasi dan dokumentasi. Dalam penelitian ini menggunakan validitas isi. Validitas isi dilakukan melalui konsultasi dengan pakar sesuai dengan variabel yang diteliti. Reliabilitas intrumen ini menggunakan metode observasi pada pengumpulan datanya.untuk mencari reliabilitas pengamatan (observasi) pada variabel bebas ini menggunakan rumus yang dikemukakan oleh H.J.X. Fernandes (Sugiyono, Metode Penelitian Pendidikan, 2014).

Teknis analisis data yang digunakan adalah uji jenjang Wilcoxon dengan taraf kesalahan 5\%. (Sugiyono, Statistika untuk Penelitian, 2016)

\section{HASIL DAN PEMBAHASAN}

\section{Deskripsi Data}

Pengamatan keterampilan motorik kasar anak untuk membandingkan keterampilan motorik kasar anak pada anak kelompok B dalam kegiatan senam di sekolah. Penelitian menggunakan pedoman lembar observasi terdiri dari 12 pernyataan untuk menilai keterampilan motorik kasar anak yang sesuai dengan STPPA (Standar Tingkat Pencapain Perkembangan Anak) selama proses kegiatan senam. Penelitian ini terdapat satu variabel yaitu keterampilan motorik kasar anak. Terdiri dari empat aspek diantaranya, kelentukan, keseimbangan, kelincahan, koordinasi. Pengamatan observasi dilakukan dengan dua orang pengamat, menggunakan pedoman lembar observasi.

\section{Pengujian Prasyaratan Analisis}

Uji prasyarat dalam penelitian ini menggunakan Uji Normalitas dengan mengacu pada rumus Kolmogorov Smirnov dengan SPSS versi 19.0 Uji ini dilakukan untuk mengetahui apakah data yang diperoleh merupakan data berdistribusi normal atau tidak berdistribusi normal.

Diketahui untuk nilai senam menggunakan irama adalah signifikansi $=0,00 \quad \alpha=0,05$. Artinya nilai signifikansi $0,00<0,05$, dan untuk senam tidak menggunakan musik adalah signifikansi $=0,00$ dengan $\alpha=0,05$. Artinya nilai signifikansi $0,00<0,05$.
Tabel. 1 Hasil Uji Normalitas

\begin{tabular}{|c|c|c|c|}
\hline & & Musik & $\begin{array}{l}\text { Tidak } \\
\overline{\text { Musik }}\end{array}$ \\
\hline \multicolumn{4}{|l|}{$\mathbf{N}$} \\
\hline Normal & Mean & 30 & 30 \\
\hline $\begin{array}{l}\text { Parameters } \\
\text { a,b }\end{array}$ & $\begin{array}{l}\text { Std. } \\
\text { Deviation }\end{array}$ & 85.45 & 72.99 \\
\hline Most & Absolute & 5.159 & 9.248 \\
\hline Extreme & Positive & .263 & .323 \\
\hline Differences & Negative & $\begin{array}{l}.163 \\
-.263\end{array}$ & $\begin{array}{l}.323 \\
-.157\end{array}$ \\
\hline $\begin{array}{l}\text { Test } \\
\text { Statistic } \\
\text { Asymp. Sig. } \\
\text { (2-tailed) }\end{array}$ & & .263 & .323 \\
\hline
\end{tabular}

Berdasarkan hasil pada tabel 1 tersebut dapat disimpulkan bahwa Ho ditolak yang artinya variabel keterampilan motorik kasar anak berdistribusi tidak normal.

\section{Uji Hipotesis}

Berdasarkan hasil dari uji normalitas data tidak berdistribusi normal. Maka, pengujian hipotesis dalam penelitian ini menggunakan uji Wilcoxon. Uji hipotesis dapat disajikan dengan tabel SPSS 19.0 sebagaimana disajikan pada tabel 2 .

Berdasarkan tabel 2 menunjukkan bahwa rata-rata peringkat negatif sebesar 15,46 sedangkan peringkat positif sebesar 16,00. Hal ini menunjukkan peringkat negatif lebih rendah dibandingkan dengan rata-rata peringkat positif.

Tabel. 2 Uji Peringkat Bertanda Wilcoxon

\begin{tabular}{|c|c|c|c|c|}
\hline & & $\mathbf{N}$ & $\begin{array}{l}\text { Mean } \\
\text { Rank }\end{array}$ & $\begin{array}{l}\text { Sum } \\
\text { of } \\
\text { Ranks }\end{array}$ \\
\hline \multirow{4}{*}{$\begin{array}{l}\text { tidak_ } \\
\text { musik } \\
- \\
\text { musik }\end{array}$} & $\begin{array}{l}\text { Negative } \\
\text { Ranks }\end{array}$ & $28^{\mathrm{a}}$ & 15.46 & 433.00 \\
\hline & $\begin{array}{l}\text { Positive } \\
\text { Ranks }\end{array}$ & $2^{b}$ & 16.00 & 32.00 \\
\hline & Ties & $0^{c}$ & & \\
\hline & Total & 30 & & \\
\hline
\end{tabular}


Tabel. 3 Uji Statistik

\begin{tabular}{|c|c|}
\hline & $\begin{array}{l}\text { Tidak musik- } \\
\text { musik }\end{array}$ \\
\hline Z & $-4.124^{b}$ \\
\hline $\begin{array}{l}\text { Asymp. } \\
\text { (2tailed) }\end{array}$ & .000 \\
\hline
\end{tabular}
disajikan dengan tabel 3 dengan bantuan software SPSS 19.0. Uji statistik hasil perhitungan uji Wilcoxon menggunakan software SPSS versi 19.0, signifikansi uji dua arah sebesar $=0,00, \alpha=0,05$. Artinya signifikansi $0,00<0,05$ maka Ho Diterima. Artinya tidak ada perbedaan keterampilan motorik kasar anak kelompok B yang menggunakan dan tidak menggunakan irama.

Berdasarkan penelitian yang berjudul Perbedaan Keterampilan Motorik Kasar Anak Kelompok B yang Menggunakan dan Tidak Munggunakan Irama Di RA Ulil Albab Kecamatan Kamal Kabupaten Bangkalan. Kegiatan observasi menggunakan pedoman lembar observasi dengan memberikan skala penilaian BM (belum berkembang), MB (mulai berkembang), BSH

(berkembang sesuai harapan), BSB (berkembang sangat baik). Instrumen penelitian ini berpedoman pada standar tingkat pencapaian perkembangan anak (STPPA). Subjek utama yang diteliti dalam penelian ini adalah anak kelompok B RA Ulil Albab.

Kegiatan pembelajaran olahraga dilaksanakan setiap hari Jum'at pagi. Kegiatan olahraga baik untuk kekuatan tulang. kegiatan berolahraga akan membuat tulang dan otot anak bertambah kuat dan banyaknya akitivitas bergerak juga akan mengontrol berat badan anak yang gemuk. (Sujino, 2014)Sebelum kegiatan senam dimulai anak-anak diminta berbaris di halaman sekolah, murid laki-laki berada di barisan depan sedangkan perempuan di barisan belakang. Guru memberikan arahan dari depan sebelum kegiatan senam dimulai.

Minggu pertama pada tanggal 02 Maret 2018, pembelajaran olahraga senam irama, saat musik dihidupkan anak-anak bersemangat mengikuti dengan iringan lagu dan ritmik yang teratur. Senam terus berlangsung sampai selesai kemudian anak-anak berkumpul di halaman duduk bersama untuk istirahat. Sedangkan minggu kedua pada tanggal 16 Maret 2018, anak-anak olahraga senam tidak menggunakan irama, anak-anak menirukan gerakan guru di depan. Beberapa kegiatannya yang dilakukan diantaranya yaitu meloncat, lari di tempat, menggerakkan pinggul, kepala, dan tangan.

Ketika senam tidak menggunakan musik berlangsung, anak-anak juga sangat senang melakukannya. Seperti merentangkan tangan, jalan jinjit, menendang, meloncat, jalan di tempat, dan berdiri satu kaki. Adapun aspek yang diteliti ada empat indikator yaitu kelentukan, keseimbangan, kelincahan, dan koordinasi.

a. Aspek Kelentukan

Menggerakkan seluruh anggota badan, mempunya empat butir pernyataan diantaranya yaitu anak mampu berdiri dengan kedua lengan diangkat ke kanan dan ke kiri, anak mampu berdiri dengan lengan ke atas dan bawah, anak mampu duduk mengkangkang tangan menyentuh ujung kaki, anak mampu duduk berhadapan dengan kedua kaki dibuka lebar ke samping dengan telapak kaki saling berpegangan tangan anak mampu menggerakkan kepala ke kiri dan ke kanan. Diketahui dari 30 anak yang melakukan kegiatan senam irama terdapat 29 anak berkembang sesuai harapan (BSH) dan satu anak mulai berkembang (MB). Sedangkan aspek kelentukan yang tidak menggunakan irama terdapat 28 anak berkembang sesuai harapan (BSH) dan dua anak mulai berkembang (MB).

b. Aspek Keseimbangan

Berdiri dan berjalan mempunyai tiga butir pernyataan diantaranya yaitu anak mampu berdiri dengan satu kaki, anak mampu berjalan jinjit, anak mampu berjalan melintasi tali. Diketeahui dari 30 anak yang melakukan kegiatan senam irama, dari tiga butir pernyataan tersebut terdapat 28 anak berkembang sesuai harapan (BSH) dan dua anak mulai berkembang (MB). Sedangkan aspek keseimbangan yang tidak menggunakan irama hampir tidak jauh berbeda. 30 anak keseluruhan berkembang sesuai harapan (BSH).

c. Aspek Kelincahan

Berlari mempunyai dua butir pernyataan diantaranya yaitu anak mampu 
Jurnal PG-PAUD Trunojoyo : Jurnal Pendidikan dan Pembelajaran Anak Usia Dini,

berlari zig-zag dan anak mampu berlari cepat. Diketahui dari 30 anak yang melakukan senam irama dalam aspek kelincahan terdapat 29 anak berkembang sesuai harapan (BSH) dan satu anak mulai berkembang (MB). Sedangkan senam yang tidak menggunakan irama terdapat 26 anak berkembang sesuai harapan $(\mathrm{BSH})$ dan empat anak mulai berkembang (MB).

d. Aspek Koordinasi

Gerakan mata, tangan, dan kaki menpunya dua butir bernyataan anak mampu melempar bola dan anak mampu menendang bola. Dalam aspek koordinasi anak melatih kesesuain gerak yang dihasilkan oleh tubuh dengan panca indra khusnya mata. Diketahui dari aspek koordinasi 30 anak yang melakukan senam irama terdapat 28 anak berkembang sesuai harapan (BSH) dan dua anak mulai berkembang (MB). Dalam kegiatan senam yang tidak menggunakan irama terdapat 21 anak berkembang sesuai harapan (BSH) dan sembilan anak berkembang sangat baik (BSB).

Berdasarkan paparan di atas, pada usia 5-6 tahun ini anak sudah baik dalam melakukan berbagai kegiatan, termasuk aktivitas senam, baik yang berirama maupun tak berirama. Hal ini sebagaimana karakteristik anak usia 5-6 tahun yakni anak sangat aktif melakukan berbagai kegiatan. Selain itu, Perkembangan bahasa dan kognitif juga semakin baik dan pesat. Bentuk permainan anak masih bersifat individu, bukan permainan sosial, walaupun aktivitas bermain dilakukan anak secara bersama. (Yusuf, 2011).

\section{SIMPULAN}

Berdasarkan anilisis data dan pembahasan tujuan penelitian ini adalah untuk mengetahui perbedaan keterampilan motorik kasar anak kelompok B pada kegiatan senam yang menggunakan irama dan tidak irama di RA Ulil Albab Kecamatan Kamal Kabupaten Bangkalan. Dilakukan uji hipotesis dengan menggunakan uji Wilcoxon, untuk mengetahui apakah ada perbedaan dalam senam yang menggunakan irama dan tidak menggunakan irama. hasil perhitungan uji Wilcoxon menggunakan SPSS 19.0, dengan signifikansi uji dua arah sebesar 0,00, karena signifikansi <
0,05 maka Ho Diterima. Maka dapat diambil kesimpulan bahwa kegiatan senam yang menggunakan irama dan tidak irama tidak ada perbedaan keterampilan motorik kasarnya.

\section{Saran}

Guru memperhatikan kondisi dan mendampingi anak-anak ketika kegiatan senam berlangsung. Hal ini penting apabila ada anak yang tidak mengikuti proses kegiatan senam, guru langsung memberikan arahan mengikuti instruktur senam yang berada di depan.

Penelitian ini diharapkan bermanfaat untuk penelitian selanjutnya dengan menggunakan variabel dan metode yang berbeda. Misal seperti membandingkan keterampilan motorik kasar dalam penggunaan alat-alat bermain di sekolah.

\section{DAFTAR PUSTAKA}

Depdiknas. (2006). Undang-Undang Republik Indonesia Nomor 20 Tahun 2003 Tentang Sistem Pendidikan Nasional. Jakarta: Depdiknas.

Fadilah, M. (2012). Desain Pembelajaran. Yogyakarta: Ar-Ruzz Media.

Hurlock, E. B. (2013). Perkembangan Anak. Jakarta: Erlangga.

Morrison, G. S. (2016). Pendidikan Usia Dini Saat Ini. Yogyakarta: Pustaka Pelajar.

Muhajir. (2007). Pendidikan Jasmani Olahraga dan Kesehatan. Jakarta: Erlangga.

Muhyi, M. (2016). Learning Trough Movement. Yogyakarta: Andi Offset.

Mujtahidin, \& Rasyid, H. A. (2014). Ilmu Pendidikan. Bangkalan: UTM Press.

Mursid. (2015). Belajar dan Pembelajaran PAUD. Bandung: PT Remaja Rosdakarya.

Sugiyono. (2014). Metode Penelitian Pendidikan. Bandung: Alfabeta.

Sugiyono. (2016). Statistika untuk Penelitian. Bandung: Alfabeta. 
122 Jurnal PG-PAUD Trunojoyo : Jurnal Pendidikan dan Pembelajaran Anak Usia Dini,

Volume 5, Nomor 2, Oktober 2018, hal 116-122

Sujino, B. (2014). Modul 1 Hakikat Perkembangan Anak. Jakarta: Universitas Terbuka.

Sumantri. (2005). Model Pengembangan Keterampilan Motorik Anak Usia Dini. Jakarta: Depdiknas.

Susanto, A. (2014). Perkembangan Anak Usia Dini. Jakarta: Kencana.

Syarifuddin, S. W. (2014). Pendidikan Jasmani, Olahraga, dan Kesehatan. Jakarta: Kemdikbud.

Yusuf, S. (2011). Psikologi Perkembangan Anak \& Remaja. Bandung: PT Remaja Rosdakarya. 